\title{
¡†rECI\&NE
}

\section{Prediction of Compressive Strengths for Rice Husks Ash incorporated concrete, Using Neural Network and Reviews}

\author{
Predicción de resistencias a la compresión para cáscaras de arroz Hormigón \\ incorporado de ceniza, utilizando redes neuronales y revisión de literatura
}

\author{
Cornelius Ngunjiri Ngandu' (1) \\ 'Egerton University, Egerton, Nakuru, Kenya, cornelius.ngandu@egerton.ac.ke ngunjiri55@yahoo.com
}

Fecha de recepción: 2 de enero de 2021. Fecha de aprobación: 16 de febrero de 2021

\begin{abstract}
Modelling of concrete that incorporates agricultural wastes such as rice husk ash (RHA) could potentially enhance utilization of green concrete and application of sustainable construction materials. This paper evaluations compressive strength prediction for rice husk ash (RHA) cementitious material incorporated concrete using artificial neural networks (ANNs) one of the various prediction methods. The research is based on various previous experimental studies.
\end{abstract}

Literature reviews of $\mathbf{7 2}$ datasets for RHA incorporated concrete from 15 previous researches, were used and subjected to ANNs models, having learning rate of 0.06 with tanh activation functions. Four (4) input variables were considered, namely:- superplasticizer or water reducers variation from control (\%), water to binder ratio, percentage of RHA and control compressive strengths. Output variable was compressive strength of RHA cementitious material incorporated concrete. The ANN with 15 neurons in the hidden layer was selected and indicated overall values of 5.10MPa, $0.99,3.81 \mathrm{MPa}$ and $9.73 \%$ for the root mean square error (RMSE), absolute factor of variance $\left(R^{2}\right)$, mean absolute error (MAE) and mean absolute percentage error (MAPE) respectively and for individual training, validation/checking and testing datasets, the RMSE, $R^{2}$, MAE and MAPE ranging between 3.98MPa-6.56MPa, 0.98-0.99, 3.44MPa-4.94MPa and $9.19 \%-12.41 \%$ respectively. Generally, both predicted and original dataset, indicated higher and lower strength values for $5-10 \%$ and $15-30 \%$ RHA incorporated cementitious material concrete respectively compared to the control strengths.

Considering that the study utilized data from different sources and with a wide range of concrete strengths the selected ANN showed relatively good performance. The study provides an indicator that machine learning techniques could accurately predict green concrete strength. Based on model performance the percentage RHA cementitious materials in concrete and the other 3 input variable had a significant impact on concrete strengths. Future research should be conducted to predict green concrete focused on particular concrete class.

Keywords- Prediction methods; concrete; artificial neural networks; Literature reviews.

Resumen- El modelado de hormigón que incorpora desechos agrícolas como la ceniza de cáscara de arroz (RHA) podría mejorar potencialmente la utilización de hormigón verde y la aplicación de materiales de construcción sostenibles. Este artículo evalúa la predicción de la resistencia a la compresión para el material cementoso de ceniza de cáscara de arroz (RHA) incorporado en el hormigón utilizando redes neuronales artificiales (ANN), uno de los diversos métodos de predicción. La investigación se basa en varios estudios experimentales previos.

Citar este artículo como: C. Ngunjiri Ngandu, Prediction of Compressive Strengths for Rice Husks Ash incorporated concrete, Using Neural Network and Reviews. ITECKNE, 18 (2), 2021 pp. 99 - 107 DOI: https://doi.org/10.15332/iteckne.v18i1.2532 
Las revisiones de la literatura de 72 conjuntos de datos para RHA incorporaron concreto de 15 investigaciones anteriores, se utilizaron y sometieron a modelos ANN, con una tasa de aprendizaje de $\mathbf{0 . 0 6}$ con funciones de activación tanh. Se consideraron cuatro (4) variables de entrada, a saber: - variación de superplastificantes o reductores de agua con respecto al control (\%), proporción de agua a aglutinante, porcentaje de RHA y resistencia a la compresión del control. La variable de salida fue la resistencia a la compresión del hormigón incorporado con material cementoso RHA. Se seleccionó la ANN con 15 neuronas en la capa oculta y se indicaron valores generales de $5.10 \mathrm{MPa}, 0.99,3.81 \mathrm{MPa}$ y $9.73 \%$ para el error cuadrático medio de la raíz (RMSE), factor de varianza absoluto $\left(R^{2}\right)$, error absoluto medio (MAE) y error de porcentaje absoluto medio (MAPE), respectivamente y para conjuntos de datos de entrenamiento, validación / verificación y pruebas individuales, el RMSE, $\mathrm{R}^{2}, \mathrm{MAE}$ y MAPE oscilan entre $3.98 \mathrm{MPa}-6.56 \mathrm{MPa}, 0.98-0.99$, 3.44MPa-4.94MPa y $9.19 \%$ - $12,41 \%$, respectivamente. En general, tanto el conjunto de datos original como el pronosticado indicaron valores de resistencia más altos y más bajos para el hormigón de material cementoso incorporado de 5-10\% y 15-30\% de RHA, respectivamente en comparación con las resistencias de control.

Teniendo en cuenta que el estudio utilizó datos de diferentes fuentes y con una amplia gama de resistencias del hormigón, la ANN seleccionada mostró un desempeño relativamente bueno. El estudio proporciona un indicador en el que las técnicas de aprendizaje automático podrían predecir con precisión la resistencia del hormigón verde. Según el desempeño del modelo, el porcentaje de materiales cementosos RHA en el concreto y las otras 3 variables de entrada tuvieron un impacto significativo en las resistencias del concreto. Se deben realizar investigaciones futuras para predecir el hormigón verde centrado en una clase de hormigón en particular.

Palabras clave- Métodos de predicción; hormigón; redes neuronales artificiales; revisiones de la literatura.

\section{INTRODUCTION}

This paper evaluations compressive strength prediction for rice husk ash (RHA) cementitious material incorporated concrete using artificial neural networks (ANNs), based on previous experimental data. Accurate predictions could promote sustainable building material usage.

Chandwani et al. [1] study on ready mix concrete modeling, the artificial neural network (ANN) model showed promising results in comparison to first-order and second-order regression techniques, for modeling unknown complex relationship exhibited by design mix proportion and concrete slump. Sathyan et al. [2] used random kitchen sink algorithm and regularized least square to predict concrete rheological and hardened properties, results indicated RMSEs and mean absolute errors (MSEs) of less than 0.05 .
According to Revathy et al. [3] the MAPE represent model performance and RMSE -Equation (3)- represent the error between the experimental and predicted results. Sathyan et al. [2] study on prediction of concrete rheological and hardened properties, input parameters enclosed weights of ingredients including cement, coarse aggregates, fine aggregates, four superplasticizers dosage and water. Islam et al. [4], ANOVA analysis indicated water to binder ratio and contents of:- cement, fine aggregate content, coarse aggregate, rice husk ash and superplasticizer, had direct effect on strength of RHA incorporated high performance concrete.

Study by Thiedeitz et al. [5] generally $40 \%$ cement replacement with RHA or fly ash indicated strong reduction of compressive strength, whereas $20 \%$ cement replacement with RHA or fly ash could even improve performance. Study by Sala et al. [6] for $10 \%$ replacement by weight of metakaolin, thermal RHA and chemical treated rice ash with raw materials from Colombia indicated that pozzolanic material incorporation increased concrete compressive strength.

Utilization of waste from rice production/processing for construction could provide alternative sustainable materials, while reducing the solid waste burden. According to Thiedeitz et al. [5], as renewable resource rice husk provides construction materials constantly, there is need for investigation on possibility of each ecologically friendly material for building. Effective predictive techniques for properties with concrete incorporated with RHA could be a step towards better structural decisions and development of proper codes of practices. Use of predictive modeling for concrete incorporated with materials from waste could provide a cost-effective techniques for green concrete quality control. The use of data from various past studies, with varying material, physical and human characteristics, would provide a good measure of the resilient levels of neural network.

This research aims at using ANN to predict concrete with partial replacement or addition of RHA as cementitious material, based on datasets from reviews of experimental research. The research considered four (4) input variables including superplasticizer or water reducers variation from control (\%), water to binder ratio, percentage of RHA and control compressive strength. The output variable is RHA binder incorporated compressive strength.

\subsection{RHA Composition, Applicability and Effects}

Study by Thiedeitz et al. [5] indicated specific surface area based on BET adsorption method for rice husk ash (grounded for 20 seconds with 20 Hertz frequency) and cement CEM $142.5 \mathrm{R}$ were $128 \mathrm{~m}^{2 /} \mathrm{g}$ and $1.24 \mathrm{~m}^{2} / \mathrm{g}$ respectively. Study by Fernandes et al. [33] on RHA from thermoelectric company in Brazil, indicated mean diameter of $19.56+0.49$ $\mu \mathrm{m}$, specific weight of $2.22+0.0028 \mathrm{~g} / \mathrm{cm}^{3}$ and specific area of $11.35+0.21 \mathrm{~m}^{2} / \mathrm{g}$, for RHA described in Table 1. Based on Fernandes et al. [33] study, the specific surface area reduced with thermal treatment temperatures. Habeeb and 
Mahmud [35] study for RHA indicated specific gravity of 2.11 as compared to 2.94 for ordinary portland cement (OPC) and loss of ignition was relatively high (5.81) for RHA as compared to that of OPC at 1.73. RHA grounded with Los Angeles machine showed decreasing average particle sizes, from $63.5 \mu \mathrm{m}$ to $11.5 \mu \mathrm{m}$ for grinding periods of 90 to 360 minutes respectively while OPC had average size of 22.1 $\mu \mathrm{m}$ according to Habeeb and Mahmud [35]. According to Yao et al. [36], RHA biomass char waste had carbon content of $82.26 \%$ of weight, specific surface area of 205.32 $\mathrm{m}^{2} / \mathrm{g}$, pore volume of $0.145 \mathrm{~cm}^{3} / \mathrm{g}$.

According to Glushankova et al. [7] results confirmed that amorphous silica is obtained from burning of rice hull in usual atmosphere and material contains silica as basis of building material manufacturing. Rice hush ashes produced by calcination at $600^{\circ} \mathrm{C}$ and calcination at $700^{\circ} \mathrm{C}$ were rather amorphous in comparison to scoria and pumice samples calcinated at corresponding temperatures, hence that explained why those RHAs had higher pozzolanic activity index (PAI) at 7 days compared to the scoria and pumice samples as reported by Mboya et al. [8]. According to Safiuddin et al. [9] RHA with silica content of $93.6 \%$ indicated RHA as highly reactive pozzolanic also obvious from high accelarated PAI at $122.4 \%$. Large quantities of $\mathrm{SiO}_{2}$ compounds in the form of cristobalite, quartz and tridymite were found in RHA as by Yao et al. [36].

According to ASTM C 618, as cited by Mboya et al. [8], the sum of the basic oxides should be over $70 \%$, for material to qualify as pozzolan. Mboya et al. [8], considered the cumulative amounts of $\mathrm{SiO}_{2}, \mathrm{Fe}_{2} \mathrm{O}_{3}$ and $\mathrm{Al}_{2} \mathrm{O}_{3}$ in $\mathrm{RHA}$, pumice and scoria samples. Table I shows selected chemical compositions for RHA from previous research all having cummulative amounts of $\mathrm{SiO}_{2}, \mathrm{Fe}_{2} \mathrm{O}_{3}$ and $\mathrm{Al}_{2} \mathrm{O}_{3}$ of $>70 \%$, hence qualifying $\mathrm{RHA}$ as pozzolanic material.

According to Islam et al. [4] study indicated portland cement with $\mathrm{CaO}$ (65.3\%), $\mathrm{SiO}_{2}(21.54 \%), \mathrm{Al}_{2} \mathrm{O}_{3}$ (5.99\%), $\mathrm{Fe}_{2} \mathrm{O}_{3}(4.45 \%)$ and Habeeb and Mahmud [35] study indicated ordinary portland cement having $\mathrm{SiO}_{2}(20.99 \%), \mathrm{Al}_{2} \mathrm{O}_{3}$ (6.19\%), $\mathrm{Fe}_{2} \mathrm{O}_{3}(3.86 \%)$ and $\mathrm{CaO}(65.96 \%)$.

According to Thiedeitz et al. [5] study, extremely high RHA surface area lead to more sites for pozzolanic reaction and high porosity causes increased water demand. Study by Cecconello et al. [32] using RHA, as partial replacement of cement, indicated that RHA pozzolanic reaction reduced porosity, with effect of RHA resulted to a reduction of total porosity of concrete mixtures. Reddy et al. [34] study indicated that for similar water to cementitious material ratios, compressive strengths of RHA modified concrete were higher compared with concrete with portland cement only, while, splitting tensile strengths, flexural strength, shrinkage strains and corrosion potential were lower for RHA modified concrete compared with concrete with portland cement only. According to Habeeb and Mahmud [35] increase in RHA fineness enhanced blended concrete strength in comparison to coarser RHA and OPC mixes.

Higher RHA silica content makes it an effective alternative to more expensive silica fume and blast furnace slag for control of corrosion, furthermore RHA is a renewable resource while fly ash is fossil-based according to Reddy et al. [34] also, high silica amount causes RHA to have potential to be utilized as pozzolanic material for blended cement concrete production in the building industry as indicated by Yao et al. [36].

Table I.

SELECTED CHEMICAL COMPOSITIONS FOR RHA FROM VARIOUS SOURCES

\begin{tabular}{|c|c|c|c|c|c|c|}
\hline $\mathrm{SiO}_{2}(\%)$ & $\begin{array}{l}\mathrm{Al}_{2} \mathrm{O}_{3} \\
(\%)\end{array}$ & $\begin{array}{c}\mathrm{Fe}_{2} \mathrm{O}_{3} \\
(\%)\end{array}$ & $\begin{array}{l}\mathrm{CaO} \\
(\%)\end{array}$ & \multicolumn{2}{|c|}{ Comment } & Source \\
\hline 81.8 & 0.38 & 0.78 & & \multicolumn{2}{|c|}{ Rice husks from Cross River state, Nigeria combusted at $500^{\circ} \mathrm{C}$} & Ettah et al. [10] \\
\hline 86.49 & 0.01 & 0.91 & 0.5 & & & Islam et al. [4] \\
\hline 93.6 & 0.02 & 0.8 & 0.38 & & & Safiuddin et al. [9] \\
\hline 91.8 & 0.06 & 0.09 & 1.02 & \multicolumn{2}{|c|}{ Rice husk heated at $10^{\circ} \mathrm{C} \mathrm{min}-1$ incinerated at $600^{\circ} \mathrm{C}$ for 3 hours } & Kawabata et al. [11] \\
\hline 95.41 & 0.00 & 0.82 & 0.00 & \multicolumn{2}{|c|}{$\begin{array}{l}\text { Husks from Minna, Nigeria. Used charcoal as solid fuel, Maximum husk temperature } \\
\text { recorded } 758^{\circ} \mathrm{C} \text { at less than } 4 \text { hours period } \& 838^{\circ} \mathrm{C} \text { for charcoal interior }\end{array}$} & Abalaka [12] \\
\hline 82.43 & 1.35 & 1.28 & 1.22 & \multicolumn{2}{|c|}{ Rice husks from Mwea, Kenya, incinerated at $600^{\circ} \mathrm{C}$ for 3 hours } & Marangu et al. [13] \\
\hline 88.02 & 0.28 & 0.31 & 2.58 & $@ 700^{\circ} \mathrm{C}, 3 \mathrm{hr}$ & Obtained from Malakand, Pakistan & Amin et al. [14] \\
\hline 89.2 & 0.67 & 0.57 & 1.09 & \multirow{2}{*}{$@ 950^{\circ} \mathrm{C}, 3 \mathrm{hrs}$} & & \multirow{2}{*}{ Getahun et al. [31] } \\
\hline 92.97 & 0.93 & 0.88 & 0.86 & & & \\
\hline 94.99 & 0.18 & 0.06 & 0.33 & \multicolumn{2}{|c|}{$\begin{array}{l}\text { From biomass combustion in fluidized bed reactor for energy generation, Brazil. The } \\
\text { company was/is selling RHA to construction firms under the name"rice husk silica" }\end{array}$} & Cecconello et al. [32] \\
\hline 96.73 & 0.09 & \multicolumn{2}{|c|}{ Not Detected } & \multicolumn{2}{|c|}{$\begin{array}{l}\text { RHA from thermoelectric company in Brazil produced through fluidized bed } \\
\text { combustion, with ascending air flow of about } 700^{\circ} \mathrm{C} \text { then milled. }\end{array}$} & Fernandes et al. [33] \\
\hline 88.32 & 0.46 & 0.67 & 0.67 & \multicolumn{2}{|c|}{$\begin{array}{l}\text { Husk from paddy field in Malaysia were burned at temperature of not more than } 690^{\circ} \mathrm{C} \text {, } \\
\text { with the fire maintained for around } 10 \text { minutes then slowly burned for more than } 1 \text { day } \\
\text { in a ferro-cement furnace. }\end{array}$} & Habeeb and Mahmud [35] \\
\hline 94.79 & 0.36 & 0.86 & 0.75 & \multicolumn{2}{|c|}{ Rice husk obtained from Shenyang, China } & Yao et al. [36] \\
\hline
\end{tabular}




\section{METHODOLOGY}

\subsection{Review and Dataset (Inputs/Outputs)}

Review of past data was conducted and for rice husk incorporated concrete, 72 datasets were identified, from 15 previous researches. Table II shows the data derived from the sources, used for artificial neural networks. Table II also shows the modifications on sourced information or data.

Table II.

72 DATASET FROM 15 REVIEWS FOR RHA INCORPORATED CONCRETE WITH MODIFICATION INDICATED

\begin{tabular}{|c|c|c|c|c|c|}
\hline $\begin{array}{l}\text { \#SP or WR \% of Binder } \\
\text { (less for control ) }\end{array}$ & "W/B ratio & $\begin{array}{c}{ }^{*} \text { Control Strength } \\
(\mathrm{Mpa})\end{array}$ & $\%$ RHA (Weight) & $\begin{array}{l}\text { Compressive } \\
\text { Strength (MPa) }\end{array}$ & Source \\
\hline $1.4100^{* * \#}$ & 0.38 & 49.8 & 10 & 52.3 & Kawabata et al. [11] \\
\hline $0.00 ; 0.00 ; 0.00$ & $0.40 ; 0.40 ; 0.40$ & 40.12 (For all) & $10 ; 12.5 ; 15$ & $40.22 ; 42.65 ; 42.08$ & Karthik et al. [15] \\
\hline $0.00 ; 0.00 ; 0.00$ & 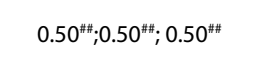 & 25.72 (For all) & $\begin{array}{c}10 ; 15 \\
20\end{array}$ & $\begin{array}{c}22.28 ; 25.12 \\
24.43\end{array}$ & $\begin{array}{c}\text { Hussin and } \\
\text { Parasuraman [16] }\end{array}$ \\
\hline $0.18967^{* * \#}$ & $0.399554^{\# \#}$ & 53.4 & $25.00^{\# \# \#}$ & 61.8 & Feltrin et al. [17] \\
\hline $0.34 * * \#$ & $0.30^{\# \#}$ & 67.7 & 5 & 87.7 & Barbosa et al. [18] \\
\hline $\begin{array}{l}0.00 \\
\text { (All) }\end{array}$ & $\begin{array}{l}0.35 ; 0.40 ; 0.40 ; 0.55 ; 0.55 \\
0.55 ; 0.55 ; 0.55 ; 0.45 ; 0.45 \\
0.45 ; 0.50 ; 0.50 ; 0.50 ; 0.50\end{array}$ & $\begin{array}{l}66.25 ; 57.79 ; 57.79 ; \\
42.95 ; 42.95 ; 42.95 ; \\
42.95 ; 42.95 ; 51.07 ; \\
51.07 ; 51.07 ; 45.98 ; \\
45.98 ; 45.98 ; 45.98\end{array}$ & $\begin{array}{c}5 ; 5 ; 10 ; 5 ; \\
10 ; 15 ; \\
20 ; 25 ; 5 ; 10 ; 15 ; 5 ; 10 ; 15 ; 20\end{array}$ & $\begin{array}{c}54.91 ; 65.96 ; 55.02 ; \\
44.1 ; 42.88 ; 41.61 ; \\
38.82 ; 34.71 ; 52.17 ; \\
50.48 ; 45.08 ; 46.85 ; \\
49.42 ; 46.66 ; 39.11\end{array}$ & Abalaka [12] \\
\hline $\begin{array}{c}0.00 ; 0.00 ; \\
0.00 ; 0.00^{* * \# ;} ; \\
0.00^{* * \#} ; 0.00^{* * \# ;} \\
0.00^{* * \#} ; 0.00^{* * \# ;} ; \\
0.00^{* * \#}\end{array}$ & $\begin{array}{c}0.55 ; 0.55 \\
0.55 ; 0.25 \\
0.25 ; 0.25 \\
0.25 ; 0.25 \\
0.25\end{array}$ & $\begin{array}{c}34.5 ; 34.5 ; \\
34.5 ; 82.3 ; \\
82.3 ; 82.3 \\
91.2 ; 91.2 \\
\quad 91.2\end{array}$ & $\begin{array}{c}10 ; 20 \\
30 ; 10 ; \\
20 ; 30 \\
10 ; 20 \\
30\end{array}$ & $\begin{array}{c}41.7 ; 39.7 ; \\
35.8 ; 100.1 ; \\
97.6 ; 88.5 ; \\
107 ; 104.2 \\
98.6\end{array}$ & $\begin{array}{c}\text { Amin and Abdelsalam } \\
{[19]}\end{array}$ \\
\hline $\begin{array}{c}0.23^{* * \#} ; 0.30^{* * \#} ; \\
0.35^{* * \#}\end{array}$ & $\begin{array}{l}\text { 0.33;0.33; } \\
\text { 0.33; }\end{array}$ & 43 (For All) & $\begin{array}{l}10 ; 15 \\
20\end{array}$ & $\begin{array}{l}44.2 ; 42.8 \\
41.8\end{array}$ & Amin et al. [14] \\
\hline $\begin{array}{c}0.00 ; 0.00 \\
0.00\end{array}$ & $\begin{array}{c}0.50 ; 0.50 \\
0.50\end{array}$ & $\begin{array}{c}27.43 \\
\text { (For All) }\end{array}$ & $\begin{array}{l}10 ; 20 \\
30\end{array}$ & $\begin{array}{c}25.8 ; 22.73 \\
19.6\end{array}$ & Oyejobi et al. [20] \\
\hline $\begin{array}{l}0.05^{* * \# ;} ; 0.11^{* * \# ;} \\
0.17^{* * \#} ; 0.46^{* * \# ;} ; \\
0.25^{* * \#} ; 0.30^{* * \# ;} \\
0.60^{* * \# ;} ; 0.85^{* * \#}\end{array}$ & $\begin{array}{l}0.38 ; 0.38 \\
0.38 ; 0.38 ; \\
0.36 ; 0.36 ; \\
0.36 ; 0.36\end{array}$ & $\begin{array}{c}61 ; 61 ; \\
61 ; 61 ; \\
61.5 ; 61.5 \\
61.5 ; 61.5\end{array}$ & $\begin{array}{c}5 ; 10 ; \\
15 ; 20 ; \\
5 ; 10 ; \\
15 ; 20\end{array}$ & $\begin{array}{l}62 ; 64.2 ; \\
61.5 ; 60.4 ; \\
60.6 ; 66.7 ; \\
62.9 ; 62.5\end{array}$ & Mahmud et al. [21] \\
\hline $\begin{array}{l}0.00 ; 0.00 \\
0.00\end{array}$ & $\begin{array}{c}0.45^{\# \#} ; 0.45^{\# \# ;} ; \\
0.45^{\# \#}\end{array}$ & $\begin{array}{l}50.3 ; \\
(A l l)\end{array}$ & $\begin{array}{l}7 ; 10 \\
15\end{array}$ & $\begin{array}{c}54.4 ; 59 \\
63.2\end{array}$ & $\begin{array}{l}\text { Ramezanianpour et } \\
\text { al. [22] }\end{array}$ \\
\hline $\begin{array}{l}0.00 \\
\text { (All) }\end{array}$ & $\begin{array}{l}0.60 ; 0.60 ; \\
0.60 ; 0.60 ; \\
0.65 ; 0.65 ; \\
0.65 ; 0.65 ; \\
0.70 ; 0.70 ; \\
0.70 ; 0.70\end{array}$ & $\begin{array}{l}26.26 ; 26.26 ; \\
26.26 ; 26.26 ; \\
24.42 ; 24.42 ; \\
24.42 ; 24.42 ; \\
21.92 ; 21.92 ; \\
21.92 ; 21.92\end{array}$ & $\begin{array}{c}5 ; 10 ; \\
15 ; 20 ; \\
5 ; 10 ; \\
15 ; 20 ; \\
5 ; 10 ; \\
15 ; 20\end{array}$ & $\begin{array}{c}25.4 ; 23.44 ; \\
21.24 ; 19.42 ; \\
23.44 ; 22.11 ; \\
20.41 ; 19 ; \\
20.83 ; 19.54 ; \\
18.95 ; 17.01\end{array}$ & $\begin{array}{l}\text { Akindahunsi and Alade } \\
{[23]}\end{array}$ \\
\hline $\begin{array}{l}0.00 \\
\text { (All) }\end{array}$ & $\begin{array}{l}0.55 ; 0.55 \\
0.55 ; 0.55\end{array}$ & 25.77 (For All) & $\begin{array}{l}5 ; 10 \\
15 ; 20\end{array}$ & $\begin{array}{c}34.68 ; 35.15 \\
31.82 ; 29.1\end{array}$ & Jeong et al. [24] \\
\hline $\begin{array}{l}0.00 \\
\text { (All) }\end{array}$ & $\begin{array}{c}0.389^{\# *} ; 0.450^{\# *} ; \\
0.503^{\# *} ; \\
0.565^{\# *}\end{array}$ & $\begin{array}{l}\text { 34.1388; } \\
34.1388 ; \\
34.1388 ; \\
34.1388\end{array}$ & $\begin{array}{l}5 \\
10 \\
15 \\
20\end{array}$ & 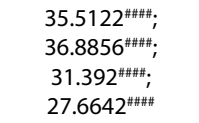 & Sung et al. [25] \\
\hline $0.00 ; 0.00$ & $0.52 ; 0.52$ & $23.3 ; 23.3$ & $10 ; 20$ & $40.0^{\# \# * * *} ; 34.5^{\# \# * * *}$ & Lee et al. [26] \\
\hline
\end{tabular}

Note: The values divided by semicolons (;) are in respective order

${ }^{*}$ Control strength is the compressive strength of sample with $0 \%$ RHA;

${ }^{* * *}$ Superplasticizer/ water reducer converted/calculated to \%;

${ }^{* *}$ The value is the difference of Superplasticizer/water reducer of Binder from control sample in percentage;

"W/B:- Water (or effective water) to binder ratio, SP:- Superplasticizer, WR:- Water reducer;

\#\#/B ratio derived/calculated/recalculation from values;

\#\#\# Estimated percentage of RHA calculated/converted to weight;

\#\#\#\# The compressive strength converted/calculated to Mpa;

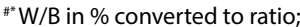

$\# \# * *$ Estimated strengths from graph;

* Data set per source not inclusive of control 
From the Table II compressive strength of RHA incorporated concrete ranged between $17.01 \mathrm{MPa}$ to $107 \mathrm{MPa}$ and the RHA binder material ranged between estimates of $5 \%$ to $30 \%$ by weight. Dataset was normalised and divided into three namely training, validation/checking and testing dataset. Hasanzade-Inallu et al. [27] used artificial neural networks (ANNs), implemented in MATLAB R2019a trained using bat algorithm, to bring various input and output variables to similar ranges, each variable was normalized, by subtraction of minimum and division by its range and output network must be denormalized by the reverse process. Input and output data are normalized to improve generalization ability of artificial neural network and better comparison and avoidance of influence of value parameters, data normalization is scaling of all inputs and outputs pairs with range $(0,1)$, based on Equation ( 1$)$ and model output is obtained in the normalized output form (scaled value), then de-normalized according to Equation (2) as indicated by Henigal et al. [28]. Datasets for this study were normalised and predicted values were de-normalized based on Equations (1) and (2) respectively.

$$
\text { Scaledvalue }=\frac{\text { Originalvalue }- \text { Minimumvalue }}{\text { Maxmumvalue }- \text { Minimumvalue }}(1)
$$

OriginalValue $=$ ScaledValue $x(\max$ imumvalue $-\min$ imumvalue $)+\min$ imumvalue $(2)$

Sathyan et al. [2] used random kitchen sink algorithm and regularized least square to predict concrete rheological and hardened properties, with 32 data sets (80\%) used for training and 8 datasets (20\%) for testing. Revathy et al. [3] used various types of network functions, one of the types using algorithm BFGS quasi- Newton back propagation, indicated using 34 datasets for training, 8 for validation and 8 for testing. For this study, the 72 data were divided into 51 (70.83\%) for training, 10 (13.89\%) for validation or checking and $11(15.28 \%)$ for testing. The selection of the three dataset was done using multiple randomilization of dataset, with the variables averages of overall and the three grouped datasets checked so that to ensure that no extremely large, biases occurred.

According to Abalaka [12] study, as the water to binder ratio increased, the quantity of maximum RHA replacement increased. According to Hussin and Parasuraman [16], there was a decrease in slump with increase percentage of RHA, with higher water demand for RHA due to higher surface area of RHA compared to cement. Karthik et al. [15] study indicated maximum strength at $12.5 \% \mathrm{RHA}$ as binder replacement was 0.4 water/binder ratio. Water to binder ratio for RHA incorporated concrete affect the concrete properties hence need for consideration. Also, the impact of superplasticizer or water reducer was considered in the dataset as it affects the workability hence strength. In this study, water binder ratio and superplasticizer or water reducer quantities variations were considered.

This study was focused on the effect of partial replacement or addition of RHA as concrete cementitious material, hence the \% of RHA (by weight) was considered as the major input. There were four (4) Input values from dataset in Table II including:- SP or WR \% difference of binder from control; W/B ratio; control compressive strength (Mpa); and \% RHA by weight and one output value:- Compressive Strength (MPa) of RHA cementitious material incorporated concrete.

\subsection{Artificial Neural Networks (ANNs)}

This study used ANNs where, input layer had 4 input variable, 1 hidden layer with varying number of nodes and a output layer having 1 variable as shown in Fig. 1.

The network was developed in OCTAVE 5.2.0 version, a free software according to Eaton et al. [37]. Hasanzade-Inallu et al. [27] study, was divided into training and testing groups randomly, using ANNs with different architectures, having 1 hidden layer with different neurons.

ANNs adopted used backpropagation (backprop) algorithm. Network and backprop was adopted from Oman [38] illustration included evaluation of errors at output model being the difference between the output from the network (hypothesis) and the experimental values, taking the error at certain layer within the network and propagating it back through the network then adjustments of weights since errors are known. The network used activation functions, Tanh as refered to Gupta [39] and GeeksforGeeks [40], for both hidden and output layers and learning rate of 0.06 . Various iterations for the models were run, using trial-and-error, with an objective of selecting model with predicted values that generate lower RMSE and higher $\mathrm{R}^{2}$. Training dataset was used to train the models, then the validation/check dataset run, mainly aimed at checking performance of model after training. Models which indicated relatively good performance for particularly check/validation dataset (case-by-case assessment) were then subjected to the testing dataset.

Fig. 1. ARTIFICIAL NEURAL NETWORK INFRASTRUCTURE SHOWING THE INPUTS AND OUTPUT VARIABLES

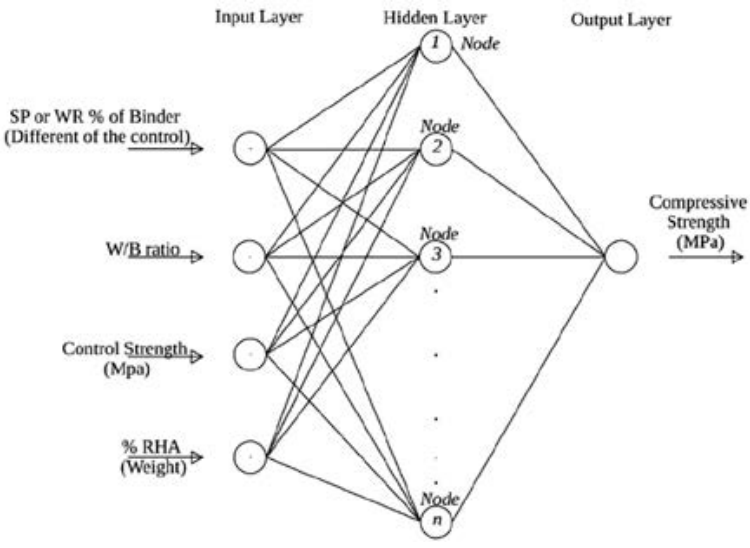

Source: the authors 


\subsection{Method for Analysis of Models}

RMSE was used in OCTAVE to check the performance of datasets after running the model. In addition LibreOffice spreadsheet were used to calculate RMSE, R ${ }^{2}$ MAE and MAPE. Zhang et al. [29] employed the Root Mean Square error (RMSE) -Equation (3)- and absolute factor of variance $\left(R^{2}\right)$ - Equation (4)- to examine deviations between the predicted and experimental values and Chandwani et al. [30] used Mean absolute Error (MAE)- Equation (5)- and Mean Absolute Percentage Error (MAPE)- Equation 6- as statistical performance metrics for evaluation of the trained models. Four evaluations- RMSE, MAE, R² \& MAPE in Equations (3) to (6) were used for this study

$$
\begin{gathered}
R M S E=\sqrt{\frac{1}{n} \sum_{i=1}^{n}}(E i-P i)^{2} \\
R^{2}=1-\frac{\sum_{i=1}^{n}(E i-O i)^{2}}{\sum_{i=1}^{n}(E i)^{2}} \\
M A E=\frac{1}{n} \sum_{i=1}^{n}|E i-O i| \\
M A P E=\frac{1}{n} \frac{\sum_{i=1}^{n}|E i-O i|}{E i} x 100
\end{gathered}
$$

Where:- $\mathrm{n}$ : No. of Data set; $\mathrm{Ei}_{\mathrm{i}}$ : Experimental Data; $\mathrm{Pi}_{\mathrm{i}}$ : Predicted Data

The RMSE and $\mathrm{R}^{2}$ for Check/Validication dataset or the overall dataset were mainly applied to indicate the model performance and selection of optimum network.

Percentage differences for the original and predicted values, from the control strength - Equation (7)- and the means were computed in LibreOffice spreadsheet.

$$
\begin{gathered}
\text { Compressivestrength }(\mathrm{MPa})- \\
\% \text { Deviation }=\frac{\text { Control } / \text { ref.strength }(M P a)}{\text { Control } / \text { ref.strength }(M P a)} \times 100 \%
\end{gathered}
$$

\section{RESULTS}

After various trials, with varying number of nodes in hidden layer or/and varying iterations, and evaluation of the entire dataset RMSE performance, the selected ANNs is presented in Table III.

Table III.

STRUCTURE OF THE SELECTED ANN

\begin{tabular}{|l|c|}
\hline \multicolumn{1}{|c|}{ Description } & Value (Comment) \\
\hline Learning Rate & 0.06 (Constant) \\
\hline Activation Function (Hidden-Output) & Tanh-Tanh (Constant) \\
\hline Hidden Layers & 15 \\
\hline Iterations & 385,000 \\
\hline
\end{tabular}

Graphical representation of experimental and predicted compressive strengths values for the selected ANN model is illustrated in Fig. 2.

Fig. 2. COMPRESSIVE STRENGTH OF PREDICTED AND EXPERIMENTAL VALUES FOR SELECTED ANN

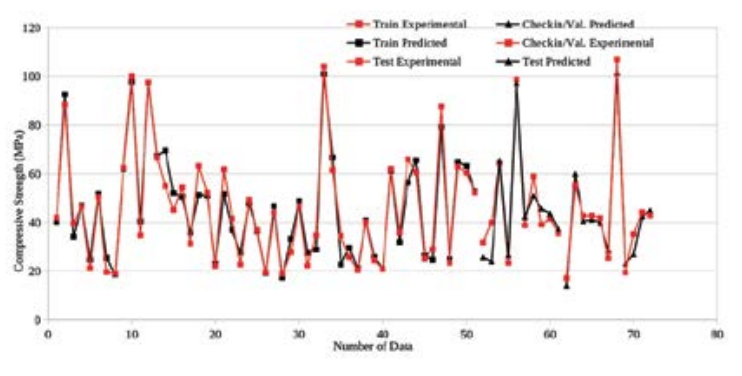

Source: the authors

The selected ANN structure in Table III, had RMSE, MAE, $\mathrm{R}^{2}$ and MAPE is presented in Table IV.

Table IV.

PERFORMANCE OF THE SELECTED MODEL BASED ON FOUR STATISTICAL METHODS

\begin{tabular}{|c|c|c|c|c|}
\hline & Training & $\begin{array}{c}\text { Validation/ } \\
\text { Check }\end{array}$ & Testing & Overall \\
\hline RMSE (Mpa) & 4.99 & 6.56 & 3.98 & 5.10 \\
\hline $\mathrm{R}^{2}$ & 0.99 & 0.98 & 0.99 & 0.99 \\
\hline MAE (Mpa) & 3.67 & 4.94 & 3.44 & 3.81 \\
\hline MAPE (\%) & 9.19 & 12.41 & 9.80 & 9.73 \\
\hline
\end{tabular}

Testing data had the lowest RMSE of 3.98MPa while the highest was validation/checking data (6.56MPa), while the $\mathrm{R}^{2}$ was between 0.98 to 0.99 for the 3 datasets. The MAE ranged between 3.44MPa and 4.94MPa and the MAPE ranged between $9.19 \%$ and $12.41 \%$, as showing in Table IV.

Table $V$ shows the \% differences from the control strengths for original dataset and predicted values based on $\%$ of $\mathrm{RHA}$ replacement or addition.

The original values mean differences for $7 \%$ and $10 \%$ RHA cemetitious material incorporate concrete were higher by $8.15 \%$ and $7.9 \%$ respectively in relation to the control strength, those being the highest and $2^{\text {nd }}$ highest for that dataset. The predicted values mean differences for $5 \%$ and $10 \%$ RHA cemetitious material incorporate concrete were higher by $5.30 \%$ and $4.12 \%$ respectively in relation to the control strength, those being the highest and $2^{\text {nd }}$ highest for that dataset.

\section{DISCUSSION}

Testing data had the lowest RMSE (3.98MPa) while the highest was validation/checking data (6.56MPa). A model 
by Islam et al. [4] 28-days strength of RHA incorporated high performance concrete, the RMSE was 4.96, an indicator of accuracy of the model fit, showing good agreement with experimental data and could be used to predict. Overall RMSE, for this study, of 5.10MPa indicates reasonable accuracy. The overall MAE was 3.81 $\mathrm{MPa}$, the lowest being for the testing with $3.44 \mathrm{MPa}$ and the highest for validation/checking data, with $4.94 \mathrm{MPa}$. Considering that datasets from different previous studies were used, with potentially wide variation of physical, human, chemical, technical/methodologies and environmental factors and also wide range of compressive strengths between $17.01 \mathrm{MPa}$ to $107 \mathrm{MPa}$ the overall RMSE and MAE values indicated quiet good accuracy. Overall $\mathrm{R}^{2}$ for the model was 0.99 , the lowest indicated by the validation/checking data, with 0.98 . Based on this, the performance of the model was accurate.

According to Revathy et al. [3], for MAPE value of less than $10 \%$ was an indication of very good performance of model and for MAPE value greater than $10 \%$, could be due to higher variation in experimental data. The MAPE values for this research was $9.73 \%$ for the overall data, with the lowest being for training data, with $9.19 \%$ and the highest for the validation/checking data, at $12.41 \%$. Based on this, with consideration to other possible influencing variations that were not quantified and the wide range of compressive strength within the study, the developed models indicated quite good accuracy, for overall data in prediction of compressive strengths for RHA incorporated concrete.

Table V, shows the percentage differences for the original data and predicted values, from the control strengths. The original values mean differences for $7 \%$ and $10 \%$ RHA cementitious material incorporate concrete were higher by $8.15 \%$ and $7.9 \%$ respectively and generally, the average percentage strength differences increased from $5 \%$ to $7 \%$ RHA cementitious material incorporate concrete, then followed by a decreasing trend, as RHA content increased, the lowest being at $-2.28 \%$ at $30 \%$ RHA replacement/addition as cementitious material. Based on the original values data, average \% differences shows that $5 \%$ to $12.5 \%$, the RHA incorporated concrete generally indicated higher strengths with those between 15 to $30 \%$ generally exhibited lower strengths compared to control strengths. Generally, both predicted and original dataset, indicated higher strength values for 5\% to 10\% RHA incorporated cementitious material concrete, while the $15 \%$ to $30 \%$ RHA cementitious contents indicated lower strength values compared to control strengths.

Table V.

PERCENTAGES DIFFERENCES OF COMPRESSION STRENGTHS FROM CONTROL AND THE MEANS

\begin{tabular}{|c|c|c|c|c|c|}
\hline \multirow[b]{2}{*}{${ }^{*}$ Control Strength (Mpa) } & \multirow{2}{*}{$\begin{array}{c}\text { \% RHA } \\
\text { (Weight) }\end{array}$} & \multicolumn{2}{|l|}{ Original Dataset } & \multicolumn{2}{|l|}{ Predicted Values } \\
\hline & & $\begin{array}{c}\text { Differences from control } \\
\text { strength }(\%)\end{array}$ & $\begin{array}{c}\text { Average } \\
(\%)\end{array}$ & $\begin{array}{l}\text { Differences from control } \\
\text { strength (\%) }\end{array}$ & $\begin{array}{c}\text { Average } \\
(\%)\end{array}$ \\
\hline $\begin{array}{c}67.7 ; 66.25 ; 61.5 ; 61 ; 57.79 ; \\
51.07 ; 45.98 ; 42.95 ; 34.1388 ; \\
26.26 ; 25.77 ; 24.42 ; 21.92 ;\end{array}$ & 5 & $\begin{array}{c}29.54 ;-17.12 ;-1.46 ; 1.64 ; 14.14 ; \\
2.15 ; 1.89 ; 2.68 ; 4.02 \\
-3.27 ; 34.58 ;-4.01 ;-4.97\end{array}$ & 4.60 & $\begin{array}{c}17.00 ; 5.09 ; 6.64 ; 0.63 ;-2.52 \\
0.03 ; 6.07 ; 9.01 ; 9.26 \\
8.37 ; 11.86 ; 2.33 ;-4.82\end{array}$ & 5.30 \\
\hline 50.3 & 7 & 8.15 & 8.15 & 0.74 & 0.74 \\
\hline $\begin{array}{c}91.2 ; 82.3 ; 61.5 ; 61 ; 57.79 ; \\
51.07 ; 50.3 ; 49.8 ; 45.98 ; 43 ; \\
42.95 ; 40.12 ; 34.5 ; 34.1388 ; 27.43 ; \\
26.26 ; 25.77 ; 25.72 ; 24.42 ; 23.3 \\
21.92 ;\end{array}$ & 10 & $\begin{array}{c}17.32 ; 21.63 ; 8.46 ; 5.25 ;-4.79 ; \\
-1.16 ; 17.30 ; 5.02 ; 7.48 ; 2.79 ; \\
-0.16 ; 0.25 ; 20.87 ; 8.05 ;-5.94 ; \\
-10.74 ; 36.40 ;-13.37 ;-9.46 ; \\
71.67 ; \\
-10.86 ;\end{array}$ & 7.90 & $\begin{array}{c}11.22 ; 18.87 ; 9.57 ; 7.41 ; 3.86 ; \\
1.31 ; 1.51 ; 5.72 ; 3.71 ;-1.31 ; \\
4.51 ; 1.65 ; 7.03 ; 6.92 ; 7.80 \\
0.60 ; 4.06 ; 6.70 ;-5.43 ; 3.09 ; \\
-12.34 ;\end{array}$ & 4.12 \\
\hline 40.12 & 12.5 & 6.31 & 6.31 & 1.11; & 1.11 \\
\hline $\begin{array}{c}61.5 ; 61 ; 51.07 ; 50.3 ; 45.98 \\
43 ; 42.95 ; 40.12 ; 34.1388 ; 26.26 \\
25.77 ; 25.72 ; 24.42 ; 21.92\end{array}$ & 15 & $\begin{array}{c}2.28 ; 0.82 ;-11.73 ; 25.65 ; 1.48 \\
-0.47 ;-3.12 ; 4.89 ;-8.05 ;-19.12 \\
23.48 ;-2.33 ;-16.42 ;-13.55\end{array}$ & -1.16 & $\begin{array}{c}5.48 ; 9.42 ; 2.04 ; 2.08 ; 2.24 \\
-4.34 ; 1.52 ; 0.62 ; 4.68 ;-5.73 \\
-0.52 ; 2.64 ;-13.41 ;-21.22 ;\end{array}$ & -1.04 \\
\hline $\begin{array}{c}91.2 ; 82.3 ; 61.5 ; 61 ; 45.98 ; \\
43 ; 42.95 ; 34.5 ; 34.1388 ; 27.43 ; \\
26.26 ; 25.77 ; 25.72 ; 24.42 ; 23.3 ; \\
21.92 ;\end{array}$ & 20 & $\begin{array}{c}14.25 ; 18.59 ; 1.63 ;-0.98 ;-14.94 ; \\
-2.79 ;-9.62 ; 15.07 ;-18.97 \\
-17.13 ; \\
-26.05 ; 12.92 ;-5.02 ;-22.19 \\
48.07 ;-22.40\end{array}$ & -1.85 & $\begin{array}{c}10.77 ; 18.53 ; 0.87 ; 3.54 ;-0.87 \\
-6.66 ;-1.62 ;-1.06 ;-2.71 ; 0.70 \\
-11.98 ;-4.14 ; 0.06 ;-23.66 ;-2.60 \\
-35.87\end{array}$ & -3.54 \\
\hline 53.4; 42.95; & 25 & 15.73;-19.19; & -1.73 & $-3.12 ;-5.62$ & -4.37 \\
\hline $91.2 ; 82.3 ; 34.5 ; 27.43$ & 30 & $8.11 ; 7.53 ; 3.77 ;-28.55$ & -2.28 & $\begin{array}{l}\text { 6.72; } 12.56 ;-7.38 \\
-7.25 ;\end{array}$ & 1.16 \\
\hline
\end{tabular}




\section{CONCLUSION}

The following are conclusions and recommendations, related to this study:-

Overall RMSE, R ${ }^{2}$ MAE and MAPE were 5.10MPa, 0.99, $3.81 \mathrm{MPa}$ and $9.73 \%$ respectively.

The ranges for the three groups of datasets (training, validation/checking and testing) for RMSE, $\mathrm{R}^{2}, \mathrm{MAE}$ and MAPE were between 3.98MPa-6.56MPa, 0.98-0.99, 3.44MPa4.94MPa and $9.19 \%-12.41 \%$ respectively.

Based on the performance of model, the \% amount of RHA as cementitious materials and the other three variables had significant impact on compressive strength.

Other physical, human, chemical, technical/methodologies and environmental factors possibly had an influence on strengths, particularly for this review that used different sources of data.

Also, there were variance in conditions, such as temperature and/or duration, for RHA production from rice husks, methodologies and concrete strengths values.

Considering 4) and 5), the selected ANN showed quite good performance. The higher error values based on the model could be attributed to those variations. This study is an indicator that machine learning techniques could be used to predict green concrete production.

Generally, both predicted and original dataset, indicated higher strength values for $5 \%$ to $10 \%$ RHA incorporated cementitious material in concrete.

This study recommends that further application of machine learning techniques for model concrete incorporated with sustainable alternative materials. There should be universal standards for production of sustainable materials, for concrete production. Future modeling for green concrete should be conducted focused to one or adjacent concrete class(es).

\section{REFERENCES}

[1] V. Chandwani, V. Agrawal, R. Nagar, and S. Singh, "Modeling Slump of Ready Mix Concrete Using Artificial Neural Network," International Journal of Technology, 2, pp.207-216, 2015.

[2] D. Sathyan, K.B. Anand, A.J. Prakash, and B. Premjith, "Modeling the fresh and hardened stage properties of selfcompacting concrete using random kitchen sink algorithm," International journal of concrete structures and materials, March 2018. DOI: https://doi.org/10.1186/s40069-018-0246-7

[3] J. Revathy, P. Gajalakshmi, and G. Ashwini, "Neural network for the prediction of fresh properties and compressive strength of flowable concrete," Journal of Urban and environmental engineering, vol. 13 (1), pp. 183-197, 2019, DOI: https://doi.org/10.4090/juee.2019.v13n1.183197
[4] N. Islam, M.F.M. Zain, and M. Jamil, "Prediction of strength and slump of rice husk ash incorporated highperformance concrete," Journal of civil engineering and management,vol. 18 (3). pp. 310-317, 2012. DOI: https://doi.org/10.3846/13923730.2012.698890

[5] M. Thiedeitz, W. Schmidt, M. Härder, and T. Kränel, "Performance of rice husk ash as supplementary cementitious material after production in the field and in the lab.," Materials, 13 (19), 4319, Sept. 2020. DOI: https://doi.org/10.3390/ma13194319

[6] A. Sala, J. Torres, R.M. Gutiérrez, and S. Delvesto, “Engineering properties of blended concrete with Colombian rice husk ash and metakaolin", Ingenieria y competitividad, vol. 15 (2), pp. 225-235, 2013

[7] I. Glushankova, A. Ketov, and M. Krasnovskikh, L. Rudakova, I. Vaisman, "Rice Hulls as a Renewable Complex Material Resource," Resources, 7 (2), 31, May 2018. DOI: https://doi.org/10.3390/resources7020031

[8] H.A. Mboya, C.K. King'ondu, K.N. Njau, and A.L. Mrema, "Measurement of pozzolanic activity index of scoria, pumice and rice husk ash as potential supplementary materials for portland cement," Advances in civil engineering, vol. 2017 Article ID 6952645, 13 pages, Aug. 2017. DOI: https://doi.org/10.1155/2017/6952645

[9] M.D. Safiuddin, J.S. West, and K.A. Soudki, "Air Content of Self-Consolidating Concrete and its Mortar Phase including Rice Husk Ash," Journal of Civil Engineering and Management, vol. 17 (3). pp. 319-329, 2011. DOI: https://doi.org/10.3846/13923730.2011.589225

[10] E.B. Ettah, J.G. Egbe, E.S. Ubi, and E.E. Okon, "Investigation of rice husk ash (RHA) as a Supplement in cement for building application," Civil Engineering Research Journal, vol. 6 (2):555681, pp. 29-34, July 2018. DOI: https://doi.org/10.19080/CERJ.2018.06.555681

[11] C.Y. Kawabata, H.S. Junior, and J. Sousa-Coutinho, "Rick husk derived waste materials as partial replacement in light weight concrete," Ciênc. Agrotec. Lavras, vol. 36 (5), pp. 567-578, 2012. DOI: https://doi.org/10.1590/S1413-70542012000500010

[12] A.E. Abalaka, "Strength and some durability properties of concrete containing rice husk ash produced in a charcoal incinerator at low specific surface," International journal of concrete structures and materials, vol. 7 (4), pp 287-293, Dec. 2013. DOI: https://doi.org/10.1007/s40069-013-0058-8

[13] J.M. Marangu, C.M. M'thiruaine, and M. Bediako, "Physicochemical Properties of Hydrated Portland Cement Blended with Rice Husk Ash," Journal of Chemistry (Hindawi), Vol. 2020, Article ID 5304745, 10 Pages, 2020. DOI: https://doi.org/10.1155/2020/5304745

[14] M.N. Amin, S. Hissans, K. Shahzada, K. Khan, and T. Bibi, "Pozzolanic reactivity and the influence of rice husk ash on early-age autogenous shrinkage of concrete," Frontier in materials (Front. Mater.), vol. 6 (150), July 2019. DOI: https://doi.org/10.3389/fmats.2019.00150

[15] M.P. Karthik, G.A. Arul, V.V. Sree, B. Manikandan, and G.M. Manasha, "Experimental study on rice husk in concrete by partial replacement," International Journal of ChemTech Research, vol. 10 (8), pp. 812-819, 2017.

[16] T.A.R. Hussin, and J. Parasuraman, "Replacement of cement with commercial available rice husk ash in concrete," Infrastructure university Kuala Lumpur Research, vol. 6(1), 2018. 
[17] C.S. Feltrin, G.C. Isaia, and A. Lübeck, "Synergic effects between mineral admixtures on strength and microstructure of concretes," Rev. IBRACON Estrut. Mater. (IBRACON Structures and Materials Journal), vol. 13 (6) el3604, 2020.

[18] M.B. Barbosa, A.M. Pereira, J.L. Akasaki, C.F. Fioriti, J.V. Fazzan, M.M. Tashima, J.J.P. Bernebeu, and J.L.P. Melges, "Impact strength and abrasion resistance of high strength concrete with rice husk ash and rubber tires," Revista IBRACON De Estruturas E Materiais (IBRACON Structures and Materials Journal), vol. 6 (5), pp. 811-820, Oct. 2013.

[19] M. Amin, and B.A. Abdelsalam, "Efficiency of rice husk ash and fly ash as reactivity materials in sustainable concrete," Sustainable Environmental Research, 29 (30), Nov. 2019. DOI: https://doi.org/10.1186/s42834-019-0035-2

[20] D.O. Oyejobi, T.S. Adbulkadir, and V. Ajibola, "Investigation of rice husk ash cementitious constituent in concrete," International journal of agricultural technology, vol. 10 (3), pp. 533-542, 2014.

[21] H. Mahmud, M.F.A. Malik, R.A. Kahar, M.F.M. Zain, and S.N. Raman,"Mechanical properties and durability of normal and water reduced high strength grade 60 concrete containing rice husk ash," Journal of advanced concrete technology, vol. 7 (1), pp. 21-30, Feb. 2009. [Online series]. Available: https:// www.jstage.jst.go.jp/article/jact/7/1/7_1_21/_pdf/-char/en [Accessed: December 18 ${ }^{\text {th }} 2020$ ].

[22] A.A. Ramezanianpour, M. Mahdi Khani, and G.H. Ahmedibeni, "The effect of rice husk on mechanical properties and durability of sustainable concretes," International journal of civil engineering, vol. 7 (2). pp 83-91, June 2009.

[23] A.A. Akindahunsi, and O. Alade, "Exploiting the potentials of rice husk ash as supplement in cement for construction in Nigeria," International journal of concrete structures and material, vol. 4 (1), pp 3-8, June 2010. DOI: https://doi.org/10.4334/IJCSM.2010.4.1.003

[24] E.C. Jeong, S.Y. Shin, and Y.S. Kim, "Durability performance of concrete using rice husk ash," Journal of the Korea Institute of Building Construction, vol. 13 (2), 2013. DOI: http://dx.doi.org/10.5345/jkibc.2013.13.2.139

[25] C.Y. Sung, B.I. Yoo, K.T. Kim, H.J. Jung, and Y.I. Kim, “An Experimental Study on the Engineering Properties of Concrete with Rice-Husk Ash," Journ. Agri. Sci. Chungnan Nat'I Univ., Korea, vol. 24 (2), pp. 207-217, 1997.

[26] M.H. Lee, S.J. Kwon, and K.T. Park, "Mechanical properties in rice husk ash and OPC concrete with coconut fiber addition ratios," Journal of the Korea Institute of Structural Maintainance and Inspection, vol. 19 (2). pp. 117-124, March 2015. DOI: http://dx.doi.org/10.11112/jksmi.2015.19.2.117

[27] A. Hasanzade-Inallu, P.H. Inallou, and B. Eskandarinezhad, "Prediction of compressive strength of concrete with manufactured sand using neural networks and bat algorithm," Soil structure interaction journal, vol. 4, pp. 52-63, 2019.

[28] A. Henigal, E. Elbeltgai, M. Eldwiny, and M. Serry, "Artificial Neural Network Model for Forecasting Concrete Compressive Strength and Slump in Egypt," Journal of Al Azhar University Engineering Sector, vol. 11 (39), pp. 435-446, April 2016.

[29] J. Zhang, Y. Zhao, and H. Li, "Experimental Investigation and Prediction of Compressive Strength of Ultra-High Performance Concrete Containing Supplementary Cementitious Materials," Advances in Material Science and
Engineering, Volume 2017, Article ID 4563164, 8 pages, Dec. 2017. DOI: https://doi.org/10.1155/2017/4563164

[30] V. Chandwani, V. Agrawal, and R. Nagar, "Modeling Slump of Ready Mix Concrete Using Artificial Neural Network," Advances in Artificial Neural Systems, Volume 2014, ArticleID 629137, 9 Pages, Nov. 2014. DOI: https://doi.org/10.1155/2014/629137

[31] M.A. Getahun, S.M. Shitote, and Z.C.A. Gariy, "Experimental Investigation on Engineering Properties of Concrete Incorporating Reclaimed Asphalt Pavement and Rice Husk Ash," Buildings, 8, 115, Aug. 2018. DOI: https://doi.org/10.3390/buildings8090115

[32] V. Cecconello, B.R.C. Sartori, M.P. Kulakowski, C.S. Kazmierczak, and M. Mancio, "Shrinkage and porosity in concrete produced with recycled concrete aggregate and rice husk ash," Revista IBRACON De Estruturas E Materiais (IBRACON Structures and Materials Journal), vol. 12 (3), pp. 694-704, Jun. 2019. DOI: https://doi.org/10.1590/S1983-41952019000300013

[33] I.J. Fernandes, D. Calheiro, F.A.L. Sánchez, A.L.D. Camacho, T.L.A.C. Rocha, C.A.M. Moraes, and V.C. Sousa, "Characterization of silica produced from rice husk ash: comparison of purification and processing methods," Materials Research, 20 (Suppl. 2), pp. 512-518, 2017. DOI: https://doi.org/10.1590/1980-5373-MR-2016-1043

[34] D.V. Reddy, M. Álvarez, and D. Arboleda, "Rice husk ash as a sustainable concrete material for marine environment," in Sixth LACCEI International Latin American and Caribbean conference for Engineering and Technology (LACCEI' 2008), Tegucigalpa, Honduras, 2008.

[35] G.A. Habeeb, and H. Mahmud, "Study on properties of rice husk ash and its use as cement replacement material," Materials Research, 13 (2), pp. 185-190, 2010.

[36] X. Yao, K. Xu, and Y. Liang, "Comparing the thermophysical properties of rice husk and rice straw as feedstock for thermochemical conversion and characterization of their waste ash from combustion," BioResources, 11 (4), pp. 10549-10564, 2016. DOI: https://doi.org/10.15376/biores.11.4.10549-10564

[37] W.J. Eaton, D. Bateman, S. Hauberg, and R. Wehbring, GNU Octave version 5.2.0 manual: A High-level interactive language for numerical computations, 2019. URL: https.//www.gnu.org/software/octave/doc/v.5.2.0

[38] S. Oman, "A Simple Neural Network in Octave-Part 2," aimatters.wordpress.com, Jan. 3,2016. [online]. Available: https://aimatters.wordpress.com/2016/01/03/a-simpleneural-network-in-octave-part-2/. [Accessed January 27th 2021].

[39] D. Gupta, "Fundamentals of Deep Learning-Activation Functions and When to Use Them?", analyticsvidhya, Jan. 30, 2020. [online]. Available: https://www.analyticsvidhya. com/blog/2020/01/fundamentals-deep-learning-activationfunctions-when-to-use-them/. [Accessed January 27th 2021].

[40] GeeksforGeeks, "Activation Functions in Neural Networks," GeeksforGeeks, Last updated 8th October, 2020. [ONLINE]. Available: https://www.geeksforgeeks.org/activationfunctions-neural-networks/ [Accessed January 18th, 2020]. 